\title{
PENGARUH BAURAN PROMOSI TERHADAP CITRA MEREK COKLAT SILVER QUEEN PADA PT. KOTAMAS PERMAI
}

\author{
Raja Saul Marto Hendry dan Daslan Simanjuntak \\ Fakultas Ekonomi dan Bisnis Universitas Labuhanbatu \\ Email : rajasaul365@gmail.com
}

\begin{abstract}
ABSTRAK
Tujuan dari penelitian ini adalah untuk mengetahui pengaruh periklanan (advertising), penjualan pribadi (personal selling), promosi penjualan (sales promotion), dan hubungan masyarakat (public relation) terhadap citra merek coklat Silver Queen. Penelitian ini menggunakan 90 responden sebagai sampel penelitian yang diambil dengan menggunakan teknik accidental sampling. Hasil penelitian berdasarkan uji secara serempak (uji $F$ ) menunjukkan bahwa secara simultan (serempak) periklanan (advertising), penjualan pribadi (personal selling), promosi penjualan (sales promotion), dan hubungan masyarakat (public relation) berpengaruh positif dan signifikan terhadap citra merek coklat Silver Queen pada PT. Kotamas Permai. Hasil pengujian hipotesis secara parsial (uji t) menunjukkan bahwa periklanan (advertising), penjualan pribadi (personal selling), promosi penjualan (sales promotion) berpengaruh positif dan signifikan terhadap citra merek coklat Silver Queen pada PT. Kotamas Permai, sedangkan hubungan masyarakat (public relation) berpengaruh positif tetapi tidak signifikan terhadap citra merek coklat Silver Queen pada PT. Kotamas Permai. Berdasarkan hasil uji determinasi diketahui bahwa citra merek dapat dijelaskan oleh periklanan (advertising), penjualan pribadi (personal selling), promosi penjualan (sales promotion), dan hubungan masyarakat (public relation), sedangkan sisanya 46,1\% dijelaskan oleh variabel lain yang tidak diteliti dalam penelitian ini, misalnya reputasi perusahaan, kualitas produk, dan lain sebagainya.

Kata kunci : Periklanan (advertising), Penjualan pribadi (personal selling), Promosi penjualan (sales promotion), Hubungan masyarakat (public relation), dan Citra merek.
\end{abstract}

\section{PENDAHULUAN}

Industri makanan ringan merupakan salah satu industri yang sangat pesat perkembangannya di dunia termasuk di Indonesia. Industri makanan ringan merupakan pasar yang kompetitif dengan banyaknya brand-brand yang berkecimpung di dalamnya. Salah satu diantaranya adalah produk coklat Silver Queen. Pasar panganan cokelat di Indonesia diisi oleh banyak pemain, baik lokal maupun asing, antara lain : PT Ceres, Cadbury, Netsle, The Mars Group, Arnotts, Nabisco, PT Mayora Indah, PT Ultra Prima Abadi, dan sebagainya. PT Ceres merupakan sebuah contoh kesuksesan produsen panganan cokelat di indonesia. Perusahaan yang membawahi brand-brand besar seperti Silver Queen, Tops dan Delfi ini memiliki bagian yang besar dalam pasarnya.

Persaingan yang semakin ketat antar perusahaan menuntut tiap perusahaan semaksimal mungkin untuk mempromosikan produknya semenarik mungkin. Menurut konsep pemasaran, berhasilnya suatu perusahaan apabila perusahaan tersebut dapat memenuhi kebutuhan konsumen dengan lebih baik. Hal ini menunjukkan bahwa perusahaan tersebut telah memasuki era kompetisi. Demikian halnya dengan produk Silver Queen, dimana dalam meningkatkan penjualan Silver Queen perusahaan perlu melakukan kegiatan promosi melalui periklanan, penjualan pribadi, promosi penjualan, dan publisitas atau public relation. Tujuannya adalah agar calon konsumen lebih mengenal, memahami, serta simpati terhadap produk yang ditawarkan. 
Promosi yang dilakukan oleh perusahaan sangat berpengaruh terhadap brand image atau citra merek atas suatu produk yang ditawarkan oleh perusahaan, karena dengan adanya brand image produk maka promosi yang dilakukan pun disesuaikan dengan citra yang melekat pada produk yang dihasilkan oleh perusahaan, tujuan dilakukan promosi agar dapat memberikan informasi atas kelebihan-kelebihan dan keunggulan produk yang ditawarkan oleh perusahaan serta membujuk calon pembeli.

Adapun strategi bauran promosi yang dilakukan oleh PT. Kotamas Permai adalah melalui periklanan, promosi penjualan, personal selling dan hubungan masyarakat (public relation). Periklanan dilakukan melalui media cetak dan media elektronik. Kemudian promosi penjualan (sales promotion) dengan memberikan diskon harga dan hadiah langsung. Penjualan pribadi (personal selling) dilakukan dengan menerjunkan tenaga-tenaga pemasaran. Hubungan masyarakat (public relation) dilakukan melalui publikasi atau menjadi sponsor pada eventevent tertentu. Hal ini dimaksudkan agar brand image atau citra coklat Silver Queen yang ditawarkan oleh perusahaan melekat di hati konsumen.

\section{TINJAUAN PUSTAKA}

\section{Bauran Promosi (Promotion Mix)}

\section{a. Pengertian Bauran Promosi}

Bauran Promosi (Promotion Mix), dalam hal mengungkapkan kebijaksanaan promosi perlu memperhatikan kegiatan-kegiatan promosi yang perlu dipertimbangkan agar diperoleh suatu kebijaksanaan yang objektif.

Menurut Wijayanto (2012:297), mengatakan bahwa bauran promosi (promotional mix) adalah kombinasi cara dalam mempromosikan produk, yaitu antara lain meliputi iklan (advertising), penjualan personal (personal selling), promosi penjualan (sales promotion), publikasi (publicity) dan public relation (PR). Menentukan bauran promosi memerlukan pertimbangan seperti anggaran, karakteristik target pasar, dan siklus hidup produk (product life cycle).

Menurut Stanton dalam Swastha dan Irawan (2008:349) bahwa Promotion Mix adalah kombinasi strategi yang paling baik dari variabel-variabel periklanan, personal selling, dan alat promosi lain yang semuanya direncanakan untuk mencapai tujuan program penjualan. Kita dapat melihat bahwa definisi tersebut tidak menyebutkan secara jelas beberapa variabel promotion mix selain periklanan dan penjualan pribadi. Pada dasarnya bauran promosi (promotion mix) terdiri dari empat variabel, yaitu :

1. Periklanan (advertising),

2. Promosi penjualan (sales promotion),

3. Penjualan pribadi (personal selling),

4. Publisitas dan pemasaran langsung (direct marketing).

Menurut Kotler dan Amstrong (2008:116), bauran promosi merupakan paduan spesifik iklan, promosi penjualan, hubungan masyarakat, penjualan personal, dan sarana pemasaran langsung yang digunakan perusahaan untuk mengkomunikasikan nilai pelanggan secara persuasif dan membangun hubungan pelanggan. Definisi lima sarana promosi utama (Kotler dan Amstrong, 2008: 117) adalah sebagai berikut :

1. Periklanan (advertising).

2. Hubungan masyarakat (public relation).

3. Promosi penjualan (sales promotion).

4. Penjualan pribadi (personal selling).

5. Pemasaran langsung (direct marketing).

b. Periklanan (Advertising) 
Menurut Kotler dan Amstrong (2008:150), periklanan adalah semua bentuk penyajian dan promosi ide, barang, atau jasa secara nonpribadi oleh suatu sponsor tertentu yang memerlukan pembayaran. Dari pengertian tersebut dapat disimpulkan bahwa periklanan adalah bentuk komunikasi bukan pribadi atau non individu dan promosi jasa atau barang dengan sejumlah biaya melalui berbagai media yang dilakukan oleh perusahaan yang disusun dengan sedemikian rupa, sehingga menimbulkan rasa menyenangkan dan mendorong seseorang untuk melakukan pembelian.

Tujuan periklanan adalah tugas komunikasi tertentu yang dicapai dengan pemirsa sasaran tertentu selama periode waktu tertentu. Langkah pertama adalah menetapkan tujuan periklanan. Tujuan-tujuan ini harus didasarkan kepada keputusan masa lalu tentang pasar sasaran, positioning, dan bauran pemasaran, yang mendefinisikan tugas yang harus dilaksanakan iklan dalam program pemasaran total. Keseluruhan tujuan periklanan adalah membantu membangun hubungan pelanggan dengan mengkomunikasikan nilai pelanggan.

\section{c. Hubungan Masyarakat (Public Relation)}

Menurut Kotler dan Armstrong (2008:168) hubungan masyarakat adalah membangun hubungan baik dengan berbagai masyarakat atau perusahaan untuk memperoleh publisitas yang diinginkan, membangun citra perusahaan yang baik, dan menangani atau menghadapi rumor, cerita, dan kejadian yang tidak menyenangkan.

Upaya humas ditujukan pada sejumlah pihak termasuk para pegawai, pemasok, pemegang saham, pemerintah, publik, kelompok, tenaga kerja, kelompok LSM, dan konsumen. Menurut Kotler dan Armstrong (2008:169), dalam rangka menciptakan dan mempertahankan citra perusahaan dan produk yang positif, hubungan masyarakat (public relation) menjalankan sejumlah fungsi utama, yaitu :

1. Hubungan pers (Press relation), menyajikan berita dan informasi mengenai organisasi sepositif mungkin.

2. Publikasi produk (Product publicity), hal ini dilakukan dengan mensponsori berbagai acara sebagai usaha untuk mempublikasikan produk.

3. Komunikasi perusahaan (Corporate communication), mengupayakan pemahaman mengenai organisasi melalui komunikasi internal dan eksternal.

4. Lobi (Lobbying), berhubungan dengan badan pembuat undangan-undangan dan pejabat pemerintah untuk mendukung atau menentang undang-undang dan peraturan.

5. Pemberian nasehat (Counselling), menasehati manajemen mengenal masalah publik dan posisi serta citra perusahaan. Pemberian nasehat ini termasuk juga pada saat terjadi kesalahpahaman produk dan kekurangpercayaan masyarakat terhadap produk perusahaan.

\section{d. Penjualan Pribadi (Personal Selling)}

Kotler dan Amstrong (2008:182) menyatakan penjualan pribadi adalah presentasi pribadi oleh wiraniaga perusahaan dengan tujuan melakukan penjualan dan membangun hubungan pelanggan. Personal selling merupakan alat yang paling efektif dalam segi biaya pada tahap lebih lanjut dalam proses pembelian, terutama dalam membangun preferensi, keyakinan, dan tindakan pembeli.

\section{e. Promosi Penjualan (Sales Promotion)}

Menurut Kotler dan Amstrong (2008:204) promosi penjualan merupakan insentif jangka pendek untuk mendorong pembelian atau penjualan produk atau jasa. Promosi penjualan meliputi pilihan sarana yang luas (kupon, kontes, potongan harga, premi, dan lainnya) semuanya mempunyai banyak kualitas unik. Semua sarana ini menarik perhatian konsumen, menawarkan insensif, dan bisa digunakan untuk mendramatisasi penawaran produk serta meningkatkan penjualan yang lesu. Namun demikian, pengaruh promosi penjualan 
biasanya berumur pendek, dan sering tidak seefektif iklan atau penjualan pribadi dalam membangun preferensi merek jangka panjang dan hubungan pelanggan. Tujuan promosi penjualan sangat beragam. Penjual bisa menggunakan promosi penjualan untuk mendorong pembelian pelanggan jangka pendek atau meningkatkan hubungan pelanggan jangka panjang. Menurut Kotler dan Amstrong (2008:205) tujuan promosi penjualan adalah sebagai berikut :

1. Mendorong pengecer menjual barang baru dan menyediakan lebih banyak persediaan, membeli lebih awal, atau mengiklankan produk perusahaan dan memberikan ruang rak yang lebih banyak.

2.. Untuk tenaga penjual, tujuan promosi penjualan yaitu mendapatkan lebih banyak dukungan tenaga penjualan bagi produk lama/ baru atau mendorong wiraniaga mendapatkan pelanggan baru.

\section{f. Pemasaran Langsung (Direct Marketing)}

Menurut Kotler dan Amstrong (2008:221) pemasaran langsung merupakan hubungan langsung dengan konsumen individual yang ditargetkan secara hati-hati untuk meraih respon segera dan mencapai hubungan pelanggan yang abadi.

Pemasar berkomunikasi langsung dengan pelanggan, baik satu per satu dan berbasis interaktif. Di samping pembangunan merek dan hubungan pelanggan, pemasar langsung biasanya mencari respon konsumen yang langsung, segera dan terukur.

Menurut Kotler dan Amstrong (2008:222), manfaat pemasaran langsung antara lain :

1. Manfaat bagi Pembeli

Bagi pembeli, pemasaran langsung bersifat menyenangkan, mudah dan pribadi. Pemasaran langsung bersifat interaktif dan segera, pembeli dapat berinteraksi dengan penjual melalui telepon atau di situs penjual untuk menciptakan konfigurasi informasi yang tepat, produk, atau jasa yang mereka inginkan.

2. Manfaat bagi Penjual

Bagi penjual, pemasaran langsung adalah alat yang kuat untuk membangun hubungan pelanggan. Pemasaran langsung memberikan akses kepada penjual untuk meraih pembeli yang tidak dapat mereka jangkau melalui saluran lain.

Menurut Kotler dan Amstrong (2008:226), bentuk pemasaran langsung diantaranya :

1. Pemasaran pengeposan langsung

Pemasaran langsung dengan mengirimkan penawaran, pengumuman, pengingat, atau barang lain kepada seseorang di alamat tertentu.

2. Pemasaran televisi renspon langsung

Pemasaran langsung melalui televisi, termasuk iklan televisi respon langsung (info komersial) dan saluran belanja rumah.

\section{Citra Merek (Brand Image)}

\section{a. Pengertian Citra Merek}

Dalam sebuah Brand Image terkandung beberapa hal yang menjelaskan tentang merek sebagai produk, merek sebagai organisasi merek sebagai simbol. Brand Image bisa juga tercipta dari faktor-faktor lainnya. Citra merek (brand image) tercipta bias dengan waktu yang sangat lama bisa juga dengan waktu yang singkat. Hal ini tergantung dengan perusahaan itu sendiri bagaimana cara membangun citra merek dan memeliharanya.

Kadang kita tidak dapat membedakan secara jelas antara identitas dan citra. Untuk membedakannya, maka akan kita lihat pengertian masing-masing menurut Kotler dan Keller (2008:259), identitas adalah berbagai cara yang di arahkan perusahaan untuk mengidentifikasikan dirinya atau memposisikan produknya. Sedangkan citra atau image, yaitu persepsi masyarakat terhadap perusahaan atau produknya. Maka jelas jika, citra merek (brand 
image) atau citra adalah bagaimana suatu merek mempengaruhi persepsi, pandangan masyarakat atau konsumen terhadap perusahaan atau produknya.

Pengertian citra merek (brand image) menurut Kotler dan Keller, (2008:166) bahwa :

1. Anggapan tentang merek yang direfleksikan konsumen yang berpegang pada ingatan konsumen.

2. Cara orang berpikir tentang sebuah merek secara abstrak dalam pemikiran mereka, sekalipun pada saat mereka memikirkannya, mereka tidak berhadapan langsung dengan produk.

\section{METODE}

\section{Populasi dan Sampel}

Populasi dalam penelitian ini adalah toko atau kios pelanggan dari PT. Kotamas Permai yang menjual produk coklat Silver Queen. Besarnya jumlah populasi tidak dapat ditentukan secara pasti. Berdasarkan data yang diperoleh jumlah toko atau kios yang menjadi konsumen PT. Kotamas Permai sampai dengan Januari 2016 berjumlah 926 toko/kios.

Penentuan jumlah sampel dalam penelitian ini dilakukan dengan menggunakan rumus Slovin, yaitu :

$$
\begin{aligned}
& \boldsymbol{n}=\frac{\boldsymbol{N}}{\left(\mathbf{1}+\boldsymbol{N e}^{\mathbf{2}}\right)} \\
& n=\frac{926}{\left(1+926(0,1)^{2}\right)}=90,25=90 \text { responden }
\end{aligned}
$$

Teknik pengambilan sampel menggunakan metode Accidental Sampling. Menurut Sugiyono (2011:61) Accidental Sampling adalah teknik pengambilan sampel secara kebetulan, yaitu siapa saja yang secara kebetulan bertemu dan dapat digunakan sebagai sampel, bila dipandang responden yang kebetulan ditemui itu cocok sebagai sumber data.

\section{Metode Analisis Data}

\section{a. Uji Asumsi Klasik}

Sebelum data dianalisis, maka model regresi berganda harus memenuhi syarat uji asumsi klasik yang terdiri atas :

\section{1) Uji Normalitas}

Uji normalitas dilakukan untuk menguji apakah dalam model regresi, variabel bebas dan variabel terikat atau keduanya telah terdistribusi secara normal atau tidak. Model regresi yang baik adalah model yang memiliki distribusi normal atau mendekati normal. Normalitas dapat dideteksi dengan melihat penyebaran data (titik) dari sumbu diagonal dari grafik atau melihat histogram dari residualnya. Uji normalitas juga dapat dilakukan dengan menggunakan pendekatan Kolmogrov-Smirnov. Dengan menggunakan tingkat signifikansi 5\% maka jika nilai Asymp.sig (2-tailed) diatas nilai signifikansi 5\% artinya variabel residual berdistribusi normal.

\section{2) Uji Multikoliniearitas}

Uji model asumsi klasik selanjutnya adalah uji multikoliniearitas. Uji ini dilakukan untuk mengetahui apakah ada korelasi antara variabel independennya (Usman dan Sobari, 2013:75). Pengujian multikolniearitas dalam penelitian ini dilakukan dengan melihat nilai dari Variance Inflation Factor (VIF) dan nilai Tolerance-nya. Jika nilai VIF $<5$ dan nilai Tolerance-nya $>0,1$ maka tidak terjadi multikoliniearitas.

\section{3) Uji Heteroskedastisitas}

Situmorang dkk (2009:122) menyatakan bahwa uji heteroskedastisitas pada prinsipnya juga ingin menguji apakah sebuah grup mempunyai varians yang sama diantara anggota grup tersebut. Jika varians sama, dan ini yang seharusnya terjadi maka dikatakan ada homoskedastisitas. Sedangkan jika varians tidak sama dikatan terjadi heterokedastisitas. 
Model regresi yang baik adalah bila tidak terjadi heteroskedastisitas. Cara yang dapat dilakukan untuk mendeteksi heteroskedastisitas adalah melihat grafik scatterplot antara nilai prediksi (*ZPRED) dengan nilai residualnya (*ZRESID). *ZPRED dan *ZRESID merupakan nilai prediksi dan residual yang telah distandarisasi. Nilainya memang berubah, tetapi skalanya tidak, sehingga tetap mencerminkan data sesungguhnya (Usman dan Sobari, 2013:78). Indikasi terjadinya heterosdekastisitas dapat dilihat bila terjadi pola sistematik tertentu pada plot seperti titik-titik yang membentuk pola yang teratur, namun bila tidak terdapat pola yang jelas serta titik-titik nya menyebar maka bisa diindikasikan model regresi bebas dari heterosdekastisitas.

\section{b. Analisis Regresi Linear Berganda}

Analisis regresi linear berganda digunakan untuk menganalisis seberapa besar pengaruh dan hubungan antara variabel bebas dengan variabel terikat. Analisis regresi berganda digunakan karena jumlah variabel bebas yang akan diteliti berjumlah lebih dari satu variabel. Dalam penelitian ini peneliti menggunakan aplikasi SPSS 20 for Windows untuk menghitung model regresi berganda ini. Rumus matematisnya adalah :

$$
\begin{aligned}
& \mathbf{Y}=\mathbf{a}+\mathbf{b}_{1} \mathbf{X}_{1}+\mathbf{b}_{2} \mathbf{X}_{2}+\mathbf{b}_{3} \mathbf{X}_{3}+\mathbf{b}_{4} \mathbf{X}_{4}+e \\
& \text { Dimana : } \\
& \text { Y } \quad=\text { Citra merek } \\
& \text { a } \quad=\text { Konstanta } \\
& \mathrm{b}_{1}, \mathrm{~b}_{2}, \mathrm{~b}_{3}, \mathrm{~b}_{4}=\text { Koefisien regresi } \\
& \mathrm{X}_{1} \quad=\text { Periklanan (advertising) } \\
& \mathrm{X}_{2} \quad=\text { Penjualan pribadi (personal selling) } \\
& \mathrm{X}_{3} \quad=\text { Promosi penjualan (sales promotion) } \\
& \mathrm{X}_{4} \quad=\text { Hubungan masyarakat (public relation) } \\
& e \quad=\text { Standar error }
\end{aligned}
$$

\section{c.Uji Hipotesis}

\section{1) Uji Parsial (Uji t)}

Pengujian ini dilakukan untuk mengetahui seberapa jauh pengaruh suatu variabel independen (X) secara parsial (individual) terhadap variasi variabel dependen (Y). Bentuk pengujiannya adalah :

- $\mathrm{H}_{0}$ : bi $=0$, artinya secara parsial periklanan $\left(\mathrm{X}_{1}\right)$, penjualan pribadi $\left(\mathrm{X}_{2}\right)$, promosi penjualan $\left(\mathrm{X}_{3}\right)$, dan hubungan masyarakat $\left(\mathrm{X}_{4}\right)$ tidak berpengaruh signifikan terhadap citra merek coklat Silver Queen (Y).

$-\mathrm{H}_{\mathrm{a}}$ : bi $\neq 0$, artinya secara parsial periklanan $\left(\mathrm{X}_{1}\right)$, penjualan pribadi $\left(\mathrm{X}_{2}\right)$, promosi penjualan $\left(\mathrm{X}_{3}\right)$, dan hubungan masyarakat $\left(\mathrm{X}_{4}\right)$ berpengaruh signifikan terhadap citra merek coklat Silver Queen (Y).

\section{2) Uji Simultan (Uji F)}

Pengujian ini dilakukan untuk melihat apakah semua variabel independen $\left(\mathrm{X}_{1}, \mathrm{X}_{2}, \mathrm{X}_{3}\right.$, dan $\mathrm{X}_{4}$ ) yang dimasukkan dalam model mempunyai pengaruh secara bersama-sama terhadap variabel dependen (Y). Bentuk pengujiannya adalah :

- $\mathrm{H}_{0}: \mathrm{b}_{1}=\mathrm{b}_{2}=\mathrm{b}_{3}=\mathrm{b}_{4}=0$, artinya secara serempak periklanan $\left(\mathrm{X}_{1}\right)$, penjualan pribadi $\left(\mathrm{X}_{2}\right)$, promosi penjualan $\left(\mathrm{X}_{3}\right)$, dan hubungan masyarakat $\left(\mathrm{X}_{4}\right)$ tidak berpengaruh signifikan terhadap citra merek coklat Silver Queen (Y).

- Ha $: b_{1} \neq b_{2} \neq b_{3} \neq b_{4}=0$, artinya secara serempak periklanan $\left(X_{1}\right)$, penjualan pribadi $\left(X_{2}\right)$, promosi penjualan $\left(\mathrm{X}_{3}\right)$, dan hubungan masyarakat $\left(\mathrm{X}_{4}\right)$ berpengaruh signifikan terhadap citra merek coklat Silver Queen (Y).

\section{3) Koefisien Determinasi $\left(R^{2}\right)$}


Determinan digunakan untuk melihat seberapa besar pengaruh variabel bebas terhadap variabel terikat. Dengan kata lain koefisien determinan digunakan untuk mengukur besarnya variabel bebas $(\mathrm{X})$ yang diteliti yaitu periklanan $\left(\mathrm{X}_{1}\right)$, penjualan pribadi $\left(\mathrm{X}_{2}\right)$, promosi penjualan $\left(\mathrm{X}_{3}\right)$, dan hubungan masyarakat $\left(\mathrm{X}_{4}\right)$ tehadap variabel terikat $(\mathrm{Y})$ yaitu citra merek. Koefisien Determinasi $\left(R^{2}\right)$ berkisar antara nol sampai dengan $1\left(0 \leq R^{2} \leq 1\right)$, hal ini berarti bila $R^{2}=0$ menunjukkan tidak adanya pengaruh variabel bebas pada variabel terikat dan bila $R^{2}$ mendekati 1 maka menunjukkan semakin kuatnya pengaruh variabel bebas kepada vaiabel terikat.

\section{HASIL DAN PEMBAHASAN}

\section{Uji Asumsi Klasik}

\section{a. Uji Normalitas}

Uji normalitas ini dilakukan untuk mengetahui apakah variabel dependen, independen, atau keduanya berdistribusi normal, mendekati normal, atau tidak. Ada dua cara untuk mendeteksi apakah residual berdistribusi normal atau tidak yaitu dengan analisis grafik dan uji statistik.

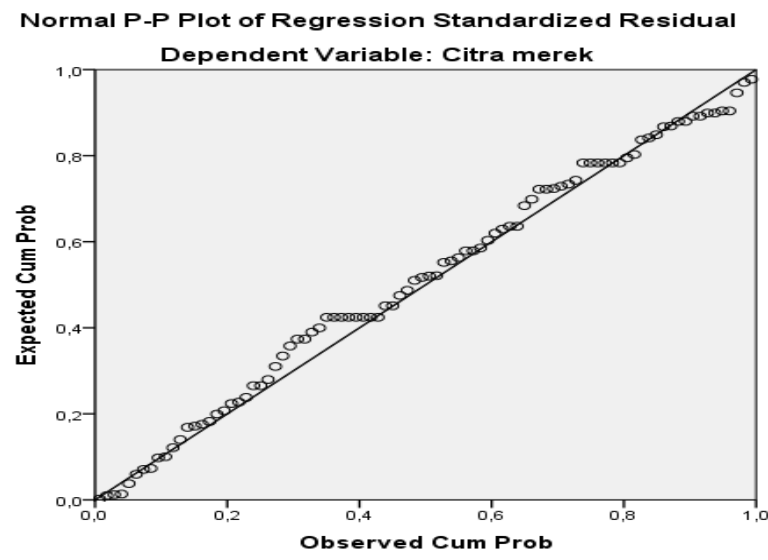

Gambar 1 Normal PP Plot

Pada Gambar 1 grafik normal PP Plot terlihat titik-titiknya menyebar disekitar garis diagonal, serta penyebarannya mengikuti arah garis diagonal. Hal ini berarti data berdistribusi normal.

Tabel 1

Hasil Uji Kolmogorov-Smirnov

One-Sample Kolmogorov-Smirnov Test

\begin{tabular}{|ll|r|}
\hline & & $\begin{array}{c}\text { Unstandardized } \\
\text { Residual }\end{array}$ \\
\hline $\mathrm{N}$ & Mean & 90 \\
Normal Parameters & OE- $\mathrm{E}-7$ \\
& Std. Deviation &, 66565167 \\
Most Extreme Differences & Absolute &, 078 \\
& Positive &, 058 \\
Kolmogorov-Smirnov Z & Negative &,- 078 \\
Asymp. Sig. (2-tailed) & &, 740 \\
\hline
\end{tabular}

a. Test distribution is Normal.

b. Calculated from data. 
Pada Tabel 1 terlihat bahwa nilai Kolmogorov-Smirnov adalah 0,740 Nilai Asymp.Sig. (2-tailed) adalah 0,644, nilai tersebut berada di atas nilai signifikan $(0,05)$. Hal ini berarti variabel residual berdistribusi normal.

\section{b. Uji Multikolinearitas}

Deteksi adanya multikolinearitas dapat dilihat pada besarnya nilai tolerance dan variance inflation factor (VIF), jika nilai tolerance $>0,1$ atau nilai VIF $<5$ dan maka tidak terdapat masalah multikolinearitas.

Tabel 2

Hasil Uji Multikolinearitas

\begin{tabular}{|ll|r|c|}
\hline \multicolumn{2}{|l|}{ Model } & \multicolumn{2}{|c|}{ Collinearity Statistics } \\
\cline { 2 - 3 } & (Constant) & & \multicolumn{1}{c|}{ Volerance } \\
\hline \multirow{2}{*}{1} & Periklanan &, 677 & 1,477 \\
& Penjualan pribadi &, 820 & 1,219 \\
& Promosi penjualan &, 639 & 1,566 \\
& Hub.masyarakat &, 931 & 1,074 \\
\hline
\end{tabular}

Pada Tabel 2 dapat dilihat bahwa nilai VIF dari setiap variabel bebas lebih kecil dari 5 sehingga data tidak terkena multikolinearias. Nilai tolerance dari setiap variabel bebas pada tabel di atas lebih besar dari 0,1 maka dapat disimpulkan bahwa data tidak terkena multikolinearitas.

\section{c. Uji Heteroskedostisitas}

Model regresi yang baik adalah yang homokedastisitas atau tidak terjadi heterokedastisitas (Situmorang, et al, 2008:65) Untuk meihat apakah terjadi heterokedastisitas atau tidak dapat dilakukan dengan pendekatan grafik maupun statistik.

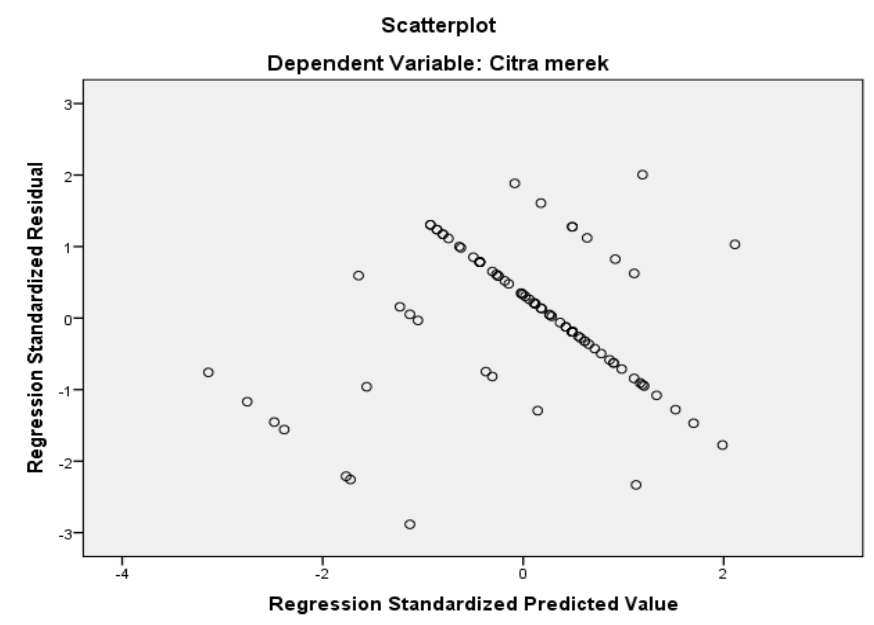

Berdasarkan Gambar 2 dapat dilihat bahwa pada tampilan grafik scatterplot, titik-titik menyebar secara acak baik di atas maupun di bawah angka 0 pada sumbu Y. dengan demikian, dapat disimpulkan bahwa tidak terjadi heteroskedastisitas pada model regresi.

Secara visual titik-titik menyebar secara acak baik di atas maupun di bawah angka 0 pada sumbu Y, padahal belum tentu data tersebut tidak terjadi heteroskedastisitas. Oleh sebab itu, pada penelitian ini analisis dilengkapi dengan uji Gletsjer. 
Tabel 3

Hasil Uji Glejser

Coefficients $^{\mathrm{a}}$

\begin{tabular}{|c|c|c|c|c|c|c|}
\hline \multirow{2}{*}{\multicolumn{2}{|c|}{ Model }} & \multicolumn{2}{|c|}{$\begin{array}{c}\text { Unstandardized } \\
\text { Coefficients }\end{array}$} & $\begin{array}{l}\text { Standardized } \\
\text { Coefficients }\end{array}$ & \multirow[t]{2}{*}{$\mathrm{t}$} & \multirow[t]{2}{*}{ Sig. } \\
\hline & & $\mathrm{B}$ & Std. Error & Beta & & \\
\hline \multirow{5}{*}{1} & (Constant) & 1,611 & ,783 & & 2,057 & ,043 \\
\hline & Periklanan &,- 061 & , 049 &,- 157 & $-1,233$ & ,221 \\
\hline & Penjualan pribadi & ,055 & ,048 & , 133 & 1,146 & ,255 \\
\hline & Promosi penjualan &,- 054 & ,056 &,- 126 &,- 960 & ,340 \\
\hline & Hub.masyarakat &,- 029 & ,050 &,- 063 &,- 581 &, 563 \\
\hline
\end{tabular}

a. Dependent Variable: AbsRes

Berdasarkan Tabel di atas, diperoleh nilai signifikansi variabel Periklanan, Penjualan Pribadi, Promosi Penjualan, dan Hubungan Masyarakat lebih besar dari tingkat signifikansi $(0,05)$. Dengan demikian dapat disimpulkan tidak terjadi gejala heteroskedastisitas dalam model regresi ini.

\section{Analisis Regresi Linear Berganda}

Analisis regresi linier berganda digunakan untuk mengetahui seberapa besar pengaruh ekuitas merek yang meliputi Periklanan $\left(\mathrm{X}_{1}\right)$, Penjualan Pribadi $\left(\mathrm{X}_{2}\right)$, Promosi Penjualan $\left(\mathrm{X}_{3}\right)$, Hubungan Masyarakat $\left(\mathrm{X}_{4}\right)$ terhadap Citra Merek (Y).

\section{Tabel 4}

Hasil Regresi Linear Berganda Coefficients $^{a}$

\begin{tabular}{|c|c|c|c|c|c|c|}
\hline \multirow{2}{*}{\multicolumn{2}{|c|}{ Model }} & \multicolumn{2}{|c|}{$\begin{array}{c}\text { Unstandardized } \\
\text { Coefficients }\end{array}$} & $\begin{array}{l}\text { Standardized } \\
\text { Coefficients }\end{array}$ & \multirow[t]{2}{*}{$\mathrm{t}$} & \multirow[t]{2}{*}{ Sig. } \\
\hline & & $\mathrm{B}$ & Std. Error & Beta & & \\
\hline \multirow{5}{*}{1} & (Constant) & ,457 & 1,320 & & ,346 & ,730 \\
\hline & Periklanan & ,355 & ,083 & ,382 & 4,273 &, 000 \\
\hline & Penjualan pribadi & ,207 & ,081 & ,209 & 2,572 & 012 \\
\hline & Promosi penjualan & ,309 & ,094 & ,302 & 3,274 & ,002 \\
\hline & Hub.masyarakat & ,089 & ,084 & 081 & 1,064 & ,290 \\
\hline
\end{tabular}

a. Dependent Variable: Citra merek

Berdasarkan Tabel 4 pada kolom Unstandardized Coefficients bagian B adalah nilai koefien regresi masing-masing variabel. Maka regresi linier berganda dirumuskan sebagai berikut :

$$
\mathrm{Y}=0,457+0,355 \mathrm{X}_{1}+0,207 \mathrm{X}_{2}+0,309 \mathrm{X}_{3}+0,089 \mathrm{X}_{4}+e
$$

Interpretasi persamaan tersebut adalah sebagai berikut :

1) Konstanta sebesar 0,457 menunjukkan bahwa jika variabel independen Periklanan $\left(X_{1}\right)$, Penjualan Pribadi $\left(\mathrm{X}_{2}\right)$, Promosi Penjualan $\left(\mathrm{X}_{3}\right)$, dan Hubungan Masyarakat $\left(\mathrm{X}_{4}\right)$, dianggap konstan, maka Citra Merek (Y) adalah sebesar 0,457.

2) Koefisien regresi $\left(b_{1}\right)$ untuk variabel Periklanan $\left(X_{1}\right)$ sebesar 0,355 menunjukkan bahwa setiap kenaikan nilai Periklanan sebesar 1 satuan, maka Citra Merek akan meningkat sebesar 0,355. Dengan asumsi variabel lain tetap (variabel lain sama dengan nol).

3) Koefisien regresi $\left(b_{2}\right)$ untuk variabel Penjualan Pribadi $\left(X_{2}\right)$ sebesar 0,207 menunjukkan bahwa setiap kenaikan nilai Penjualan Pribadi sebesar 1 satuan, maka Citra Merek akan meningkat sebesar 0,207. Dengan asumsi variabel lain tetap (variabel lain sama dengan nol).

4) Koefisien regresi $\left(b_{3}\right)$ untuk variabel Promosi Penjualan $\left(X_{3}\right)$ sebesar 0,309 menunjukkan bahwa setiap kenaikan nilai Promosi Penjualan sebesar 1 satuan, maka Citra Merek akan meningkat sebesar 0,309. Dengan asumsi variabel lain tetap (variabel lain sama dengan nol). 
5) Koefisien regresi $\left(b_{4}\right)$ untuk variabel Hubungan Masyarakat $\left(\mathrm{X}_{4}\right)$ sebesar 0,089 menunjukkan bahwa setiap kenaikan nilai Hubungan Masyarakat sebesar 1 satuan, maka Citra Merek akan meningkat sebesar 0,089. Dengan asumsi variabel lain tetap (variabel lain sama dengan nol).

\section{Pengujian Hipotesis}

\section{a. Uji Parsial (Uji t)}

Uji t digunakan untuk mengetahui pengaruh variabel-variabel independen yang terdiri dari Periklanan $\left(\mathrm{X}_{1}\right)$, Penjualan Pribadi $\left(\mathrm{X}_{2}\right)$, Promosi Penjualan $\left(\mathrm{X}_{3}\right)$, dan Hubungan Masyarakat $\left(\mathrm{X}_{4}\right)$ secara parsial terhadap variabel dependen yaitu Citra Merek (Y). Uji t dilakukan dengan cara membandingkan nilai thitung dengan $t_{\text {tabel }}$. Nilai $t_{\text {tabel }}$ yang digunakan adalah nilai distribusi t dengan derajat bebas (df) yaitu (df1) $=\mathrm{k}-1=5-1=4$, dan $(\mathrm{df} 2)=\mathrm{n}-\mathrm{k}=$ $90-5=85$. Uji thitung yang dilakukan adalah uji dua arah maka tabel yang digunakan adalah 1,66298 .

Tabel 5

Hasil Uji t

Coefficients $^{\mathrm{a}}$

\begin{tabular}{|c|c|c|c|c|c|c|}
\hline \multirow{2}{*}{\multicolumn{2}{|c|}{ Model }} & \multicolumn{2}{|c|}{$\begin{array}{l}\text { Unstandardized } \\
\text { Coefficients }\end{array}$} & $\begin{array}{c}\text { Standardized } \\
\text { Coefficients }\end{array}$ & \multirow[t]{2}{*}{$\mathrm{t}$} & \multirow[t]{2}{*}{ Sig. } \\
\hline & & B & Std. Error & Beta & & \\
\hline \multirow{5}{*}{1} & (Constant) & , 457 & 1,320 & & ,346 & ,730 \\
\hline & Periklanan & ,355 & ,083 & ,382 & 4,273 & ,000 \\
\hline & Penjualan pribadi & 207 & ,081 & 209 & 2,572 & ,012 \\
\hline & Promosi penjualan & ,309 & ,094 & ,302 & 3,274 & ,002 \\
\hline & Hub.masyarakat & ,089 & , 084 & ,081 & 1,064 & ,290 \\
\hline
\end{tabular}

a. Dependent Variable: Citra merek

Pada Tabel Uji t memperlihatkan bahwa :

1) Variabel Periklanan $\left(X_{1}\right)$ memiliki nilai thitung $(4,273)>t_{\text {tabel }}(1,66298)$ dan nilai signifikansi $(0,000)<(0,05)$, maka dapat disimpulkan Ha diterima (Ho ditolak), artinya periklanan (advertising) secara parsial berpengaruh positif dan signifikan terhadap citra merek coklat Silver Queen pada PT. Kotamas Permai.

2) Variabel Penjualan pribadi $\left(X_{2}\right)$ memiliki nilai thitung $(2,572)>t_{\text {tabel }}(1,66298)$ dan nilai signifikansi $(0,012)<(0,05)$, maka dapat disimpulkan Ha diterima (Ho ditolak), artinya penjualan pribadi (personal selling) secara parsial berpengaruh berpengaruh positif dan signifikan terhadap citra merek coklat Silver Queen pada PT. Kotamas Permai.

3) Variabel Promosi penjualan $\left(X_{3}\right)$ memiliki nilai thitung $(3,274)>t_{\text {tabel }}(1,66298)$ dan nilai signifikansi $(0,012)<(0,05)$, maka dapat disimpulkan Ha diterima (Ho ditolak), artinya promosi penjualan (sales promostion) secara parsial berpengaruh berpengaruh positif dan signifikan terhadap citra merek coklat Silver Queen pada PT. Kotamas Permai.

4) Variabel Hubungan masyarakat $\left(X_{4}\right)$ memiliki nilai $t_{\text {hitung }}(1,064)<t_{\text {tabel }}(1,66298)$ dan nilai signifikansi $(0,290)>(0,05)$, maka dapat disimpulkan Ho diterima (Ha ditolak), artinya hubungan masyarakat (public relation) secara parsial berpengaruh berpengaruh positif dan tidak signifikan terhadap citra merek coklat Silver Queen pada PT. Kotamas Permai.

\section{b. Uji Simultan (Uji F)}

Uji-F digunakan untuk mengetahui pengaruh variabel-variabel independen yang terdiri dari Periklanan $\left(\mathrm{X}_{1}\right)$, Penjualan Pribadi $\left(\mathrm{X}_{2}\right)$, Promosi Penjualan $\left(\mathrm{X}_{3}\right)$, dan Hubungan Masyarakat $\left(\mathrm{X}_{4}\right)$ secara simultan (bersama-sama) terhadap variabel dependen yaitu Citra Merek (Y). 
Nilai $F_{\text {hitung }}$ diperoleh dari pengolahan data SPSS 20.0 for Windows, kemudian akan dibandingkan dengan nilai $\mathrm{F}_{\text {tabel }}$ pada tingkat $\alpha=5 \%$. Nilai $\mathrm{F}_{\text {tabel }}$ yang digunakan adalah nilai distribusi $\mathrm{F}$ dengan derajat bebas $(\mathrm{df})$, yaitu df $1=5-1=4$, dan df $2=90-5=85$. Maka $\mathrm{F}_{\text {tabel }}$ yang digunakan adalah 2,32.

Tabel 6
Hasil Uji F
ANOVA

\section{c. Koefisien Determinasi $\left(R^{2}\right)$}

Koefisien Determinasi ( $R^{2}$ atau $R$ Square) dilakukan untuk mendeteksi seberapa jauh kemampuan model dalam menerangkan variasi variabel dependen. Nilai $R^{2}$ yang kecil berarti kemampuan variabel-variabel independen dalam menjelaskan variabel dependen amat terbatas dan sebaliknya. Apabila nilai $R^{2}$ suatu regresi (mendekati satu), maka semakin baik regresi tersebut dan semakin mendekati nol, maka variabel independen secara keseluruhan tidak bisa menjelaskan variabel dependen.

\section{Tabel 7}

\section{Koefisien Determinasi} Model Summary

\begin{tabular}{l|r|r|r|r|}
\hline Model & $\mathrm{R}$ & $\mathrm{R}$ Square & $\begin{array}{r}\text { Adjusted R } \\
\text { Square }\end{array}$ & $\begin{array}{c}\text { Std. Error of the } \\
\text { Estimate }\end{array}$ \\
\hline 1 &, $734^{\mathrm{a}}$ &, 539 &, 517 &, 681 \\
\hline
\end{tabular}
a. Predictors: (Constant), Hub.masyarakat, Promosi penjualan,
Penjualan pribadi, Periklanan

Berdasarkan Tabel 7 dapat dilihat bahwa nilai $R$ sebesar 0,734 yang berarti bahwa hubungan antara Periklanan, Penjualan Pribadi, Promosi Penjualan, dan Hubungan Masyarakat adalah kuat. Nilai Adjusted $R$ Square dalam penelitian ini yaitu sebesar 0,539 yang berarti 53,9\% variasi dari Citra Merek dapat dijelaskan oleh empat variabel bebas yaitu Periklanan, Penjualan Pribadi, Promosi Penjualan, dan Hubungan Masyarakat sedangkan sisanya 46,1\% dijelaskan oleh variabel lain yang tidak diteliti dalam penelitian ini.

\section{KESIMPULAN DAN SARAN}

Berdasarkan hasil penelitian, maka dapat diambil kesimpulan sebagai berikut :

1. Secara parsial, periklanan (advertising) berpengaruh positif dan signifikan terhadap citra merek coklat Silver Queen pada PT. Kotamas Permai.

2. Secara parsial, penjualan pribadi (personal selling) berpengaruh positif dan signifikan terhadap citra merek coklat Silver Queen pada PT. Kotamas Permai.

3. Secara parsial, promosi penjualan (sales promotion) berpengaruh positif dan signifikan terhadap citra merek Silver Queen pada PT. Kotamas Permai. 
4. Secara parsial, hubungan masyarakat (public relation) berpengaruh positif dan tidak signifikan terhadap citra merek coklat Silver Queen pada PT. Kotamas Permai.

5. Secara simultan, periklanan (advertising), penjualan pribadi (personal selling), promosi penjualan (sales promotion), dan hubungan masyarakat (public relation) berpengaruh positif dan signifikan terhadap citra merek coklat Silver Queen pada PT. Kotamas Permai.

6. Citra Merek dapat dijelaskan oleh periklanan (advertising), penjualan pribadi (personal selling), promosi penjualan (sales promotion), dan hubungan masyarakat (public relation), sedangkan sisanya $46,1 \%$ dijelaskan oleh variabel lain yang tidak diteliti dalam penelitian ini, misalnya reputasi perusahaan, kualitas produk, dan lain sebagainya.

\section{B. Saran}

Berdasarkan kesimpulan diatas, maka peneliti memberikan saran sebagai berikut :

1. Produsen coklat Silver Queen sangat perlu meningkatkan hubungan masyarakatnya dengan berbagai pihak. Hubungan yang baik suatu perusahaan dengan suatu pihak memungkinkan akan menciptakan image yang baik terhadap produk perusahaan dan memungkinkan akan memilih produk perusahaan dibandingkan produk pesaing.

2. Unsur bauran promosi dalam penelitian ini belum mengikutsertakan variabel penjualan langsung (direct selling). Oleh karena itu kepada penelitian selanjutnya diharapkan dapat menambah variabel penelitian, misalnya direct selling, reputasi perusahaan, kualitas produk, dan lain sebagainya.

\section{DAFTAR PUSTAKA}

Abdullah, Thamrin dan Francis Tantri. 2012. Manajemen Pemasaran. Jakarta : Raja Grafindo Persada.

Armaja, Isma Anugerah Mardi. 2007. "Pengaruh Bauran Promosi, Brand Image, dan Customer Reference Terhadap Keputusan Memilih Lembaga Bimbingan Belajar : Studi pada LBB Sony Sugema College Malang”. Jurnal Ekonomi. Malang : Universitas Negeri Malang.

Basu, Swastha dan Irawan. 2008. Manajemen Pemasaran Modern. Yogyakarta : Penerbit Liberty.

Basu, Swastha dan T. Hani Handoko. 2008. Manajemen Pemasaran : Analisa Perilaku Konsumen. Edisi pertama, Cetakan keempat. Yogyakarta : Penerbit BPFE.

Fitriana, Nur. 2011. "Analisis Bauran Pengaruh Promosi Word of Mouth Terhadap Brand Image dan Proses Keputusan Kunjungan Kebun Raya Bogor”. Jurnal IPB. Bogor : Institut Pertanian Bogor.

Ghozali, Imam. 2007. Aplikasi Analisis Multivariate dengan Program SPSS. Semarang : Badan Penerbit Universitas Diponegoro.

Handayani, Desy, et al. 2010. Brand Operation. Jakarta : Esensi.

Julianto, Andre. 2006, "Pengaruh Bauran Promosi Terhadap Brand Image sabun Mandi Lifebuoy (Studi Kasus Pada Mahasiswa Universitas Widyatama) Surabaya”. E-Jurnal Manajemen Vol. 4 No. 5.

Kotler, Philip dan Kevin Lane Keller. 2008. Manajemen Pemasaran, Edisi Ketigabelas, Jilid Satu. Jakarta : Erlangga.

Kotler, Philips dan Gery Armstrong. 2008. Prinsip-prinsip Pemasaran. Jilid I, Edisi kedelapan. Jakarta : Erlangga.

Kuncoro, Mudrajad. 2009. Metode Riset untuk Bisnis \& Ekonomi (Edisi 3). Jakarta : Erlangga. Machfoedz, Mahmud. 2006. Pengantar Pemasaran Modern. Cetakan pertama. Yogyakarta : Penerbit Akademi Manajemen Perusahaan YKPN.

Oentoro, Deliyanti. 2012. Manajemen Pemasaran Modern, Cetakan ketigabelas. Yogyakarta : Pressindo. 
Oesman, Marty Yevis, 2010. Sukses Mengelola Marketing Mix, CRM, Customer Value, dan Customer Dependency. Bandung : Alfabeta.

Rangkuti, Freddy. 2009. Strategi Promosi Yang Kreatif. Edisi pertama, Cetakan pertama. Jakarta : Gramedia Pustaka Utama.

Situmorang, Syafrizal Helmi dan Paham Ginting. 2009. Analisis Data Penelitian. Cetakan Kedua. Medan : USU Press.

Subagyo, Ahmad. 2010. Marketing In Business : Studi Kasus UMK \& LKM. Jakarta : Mitra Wacana Media.

Sugiyono. 2011. Statistik Untuk Penelitian. Cetakan kesembilanbelas Bandung : Penerbit Alfabeta.

Tjiptono, Fandy. 2006. Pemasaran Jasa. Edisi I. Malang : Bayumedia Pubishing.

Usman, Hardius dan Nurdin Sobari. 2013. Aplikasi Teknik Multivariate untuk Riset Pemasaran. Jakarta : PT. Raja Grafindo Persada.

Wijayanto, Dian. 2012. Pengantar Manajemen. Jakarta : Gramedia Pustaka Utama. 